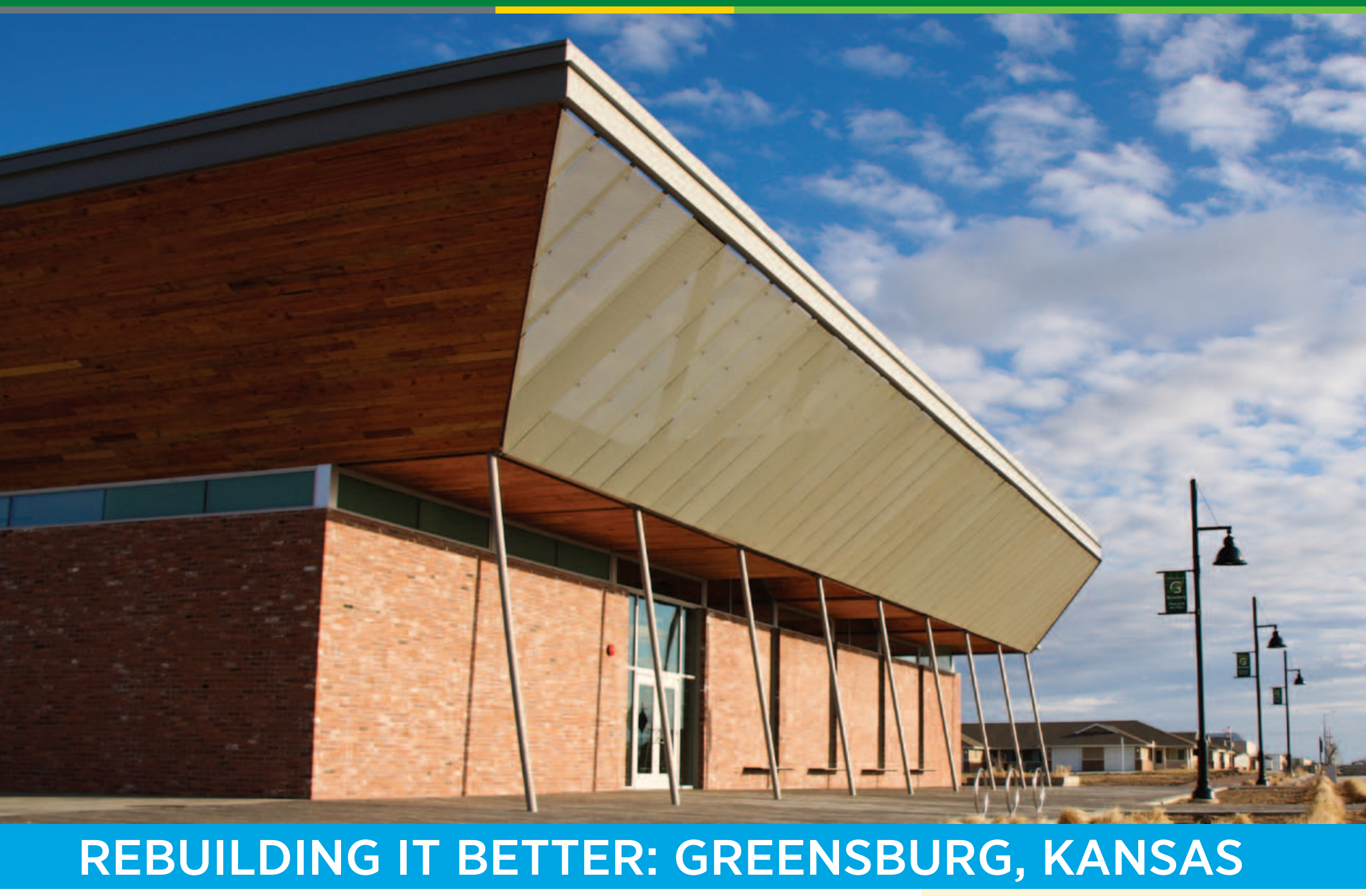

On May 4, 2007, a massive tornado destroyed or severely damaged $95 \%$ of Greensburg, Kansas. Since then, city and community leaders have been committed to rebuilding the town as a model sustainable rural community.

Experts from the U.S. Department of Energy (DOE) and the National Renewable Energy Laboratory (NREL) are working with city leaders, business owners, and residents to identify ways to incorporate energy efficiency and renewable energy technologies into the new buildings. Ultimately, these technologies could be replicated in other communities recovering from disaster.

\title{
City Hall
}

Destroyed in the tornado, City Hall has been rebuilt green incorporating solar panels, ground source heat pumps, reclaimed materials, and a vegetated roof. The building serves as a symbol of Greensburg's vitality and leadership in becoming a sustainable community where social, environmental, and economic concerns are held in balance.

The new Greensburg City Hall is projected to achieve more than $38 \%$ energy savings compared to a similar building built to standard code due in part to the 4.8-kilowatt (kW) rooftop photovoltaic (PV) system and ground source heat pumps. 


\section{$100 \%$ Renewable Energy, $100 \%$ of the Time}

The Greensburg Wind Farm consists of 101.25 megawatt (MW) wind turbines that supply $12.5 \mathrm{MW}$ of renewable power to the town. That's enough energy to power every house, business, and municipal building in Greensburg.

The town will use only about $1 / 4$ to $1 / 3$ of the power generated to reach its " $100 \%$ renewable energy, $100 \%$ of the time" goal.

Excess power will be placed back on the grid and offered as renewable energy credits for other Kansas Power Pool and NativeEnergy customers.

The wind farm was completed in the spring of 2010. John Deere Renewable Energy built the wind farm and maintains the project.

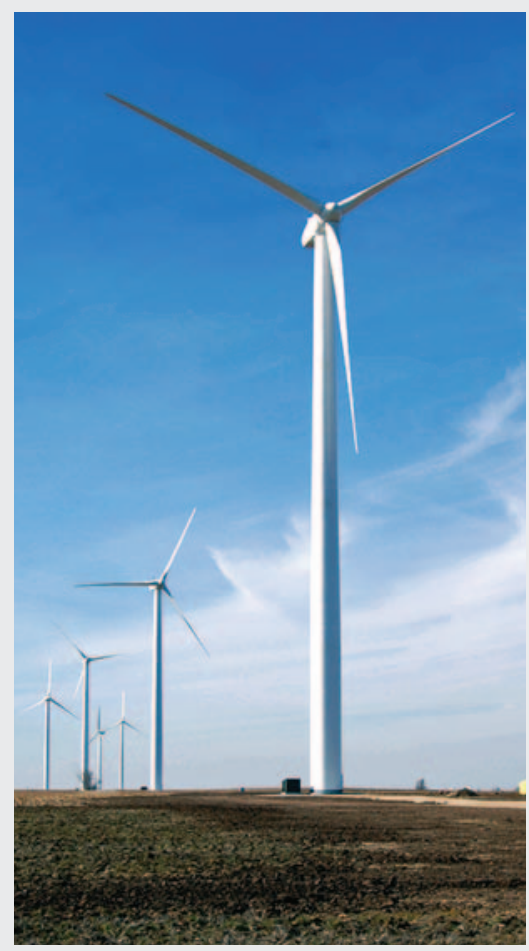

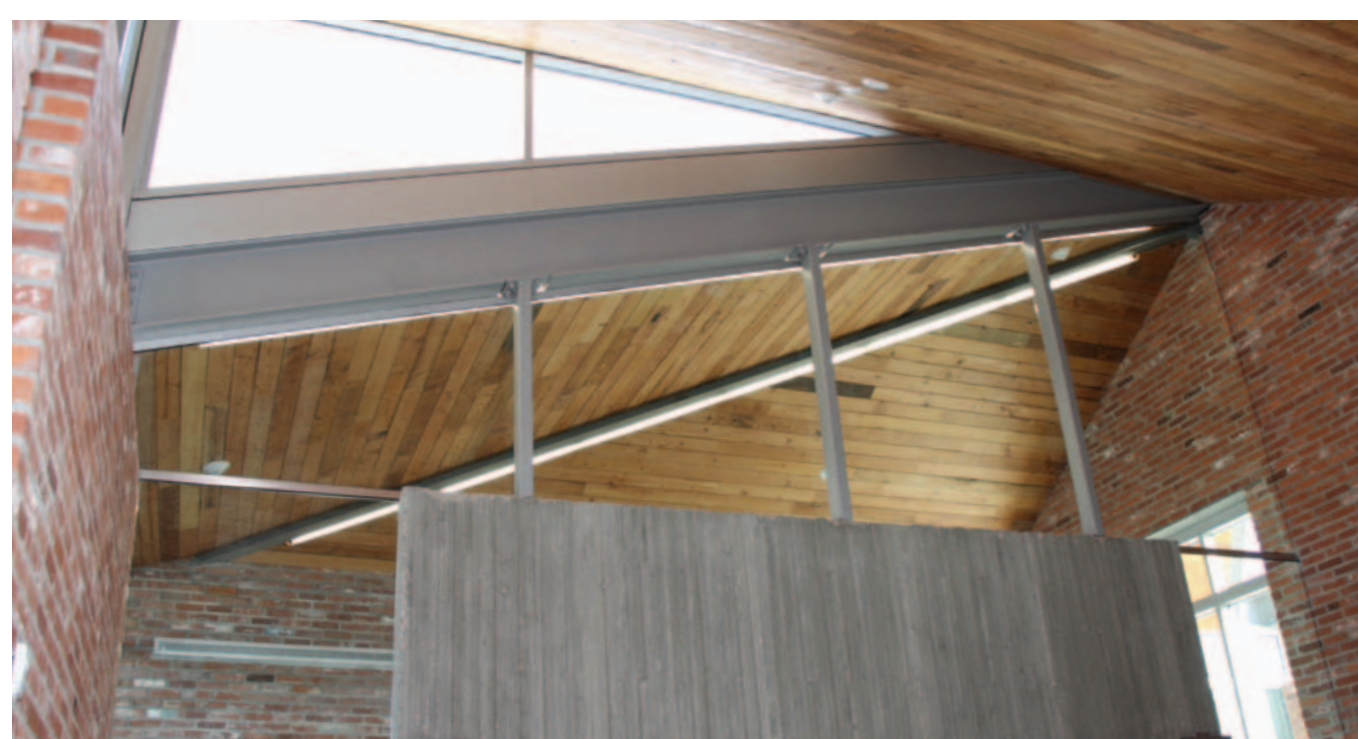

Daylighting built into the roof helps offset electrical lighting needs.

\section{LEED ${ }^{\circledR}$ Platinum}

Completed in October 2009,

Greensburg City Hall achieved the U.S. Green Building Council's Leadership in Energy and Environmental Design $\left(\right.$ LEED $\left.^{\circledR}\right)$ Platinum designation. It is the first newly constructed LEED Platinum-certified city hall building in the United States.

The 4,700-square-foot building houses the City's administrative offices and council chambers, and serves as a gathering place for town meetings and municipal court sessions.

NREL, with the support of DOE, provided technical assistance to determine the most cost-effective energy strategies for the building.

\section{Energy Conservation}

The City Hall building incorporates the following energy efficient and renewable energy technologies.

\section{Lighting}

- Daylighting and lighting controls help limit the amount of artificial light needed
- Energy-efficient exterior lights save energy at night

- High performance windows allow natural light to offset electrical lighting and reduce heat loss in winter and heat gain in summer

- A solar-powered outdoor sign, designed to resemble the exterior of City Hall, gathers and stores electricity to illuminate the sign at night using energy-efficient light emitting diodes (LEDs)

\section{Building Envelope and Insulation}

- R-22 insulated concrete forms insulate the building

- A thin film PV panel is integrated into the standing seam metal roof with polyisocyanurate insulation providing an insulation value of R-30

- South-facing roof surfaces are sloped at an angle to harness solar energy 
The City of Greensburg is committed to

providing quality services to our community in a

sustainable manner. City Hall is proof that we are

committed to smart growth and quality of life.

Steve Hewitt, Administrator

City of Greensburg

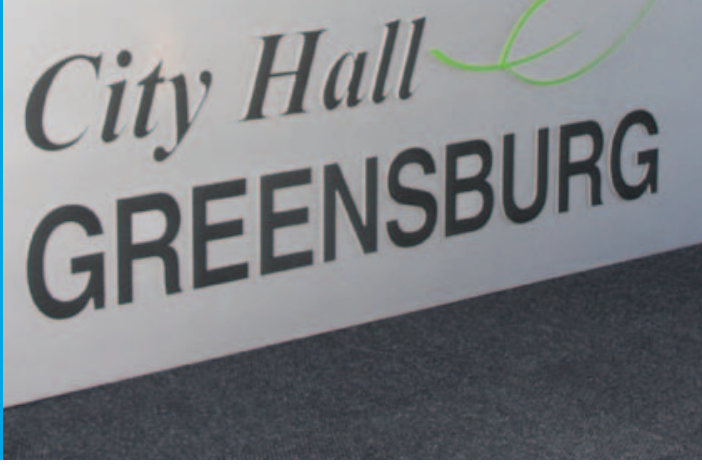

The solar-powered City Hall sign, designed to resemble the building's exterior, uses LEDs for nighttime illumination.

\section{Materials}

City Hall is constructed with durable and meaningful materials, including regional Elmwood and reclaimed brick from the destroyed Greensburg Power Plant. Materials made of recycled content are used throughout the building, including Gypsum wall board, solid surface sills, countertops, and ceramic tiles. An effort was made to use both interior and exterior materials that were extracted and manufactured within the region.

\section{Indoor Air Quality}

To ensure a healthy and safe environment for employees and visitors, nontoxic, low volatile organic compound products were used, including paint, adhesives, sealants, interior composite wood, and agrifiber items. The City plans to survey building occupants within six to 18 months of occupancy; if more than $20 \%$ of staff are dissatisfied with air quality the city will develop a plan of corrective action.
- An open-loop ground source heat pump system provides heating and cooling

\section{Water Efficiency}

Dual-flush toilets and waterless urinals reduce wastewater generation by more than $50 \%$. Additional water-saving measures include low-flow faucets with automatic controls and rainwater collection and storage on the rooftop garden. The garden absorbs large amounts of water that is used to irrigate the native plant landscape. 
The City Council chambers incorporates reclaimed brick from the destroyed Greensburg Power Plant.

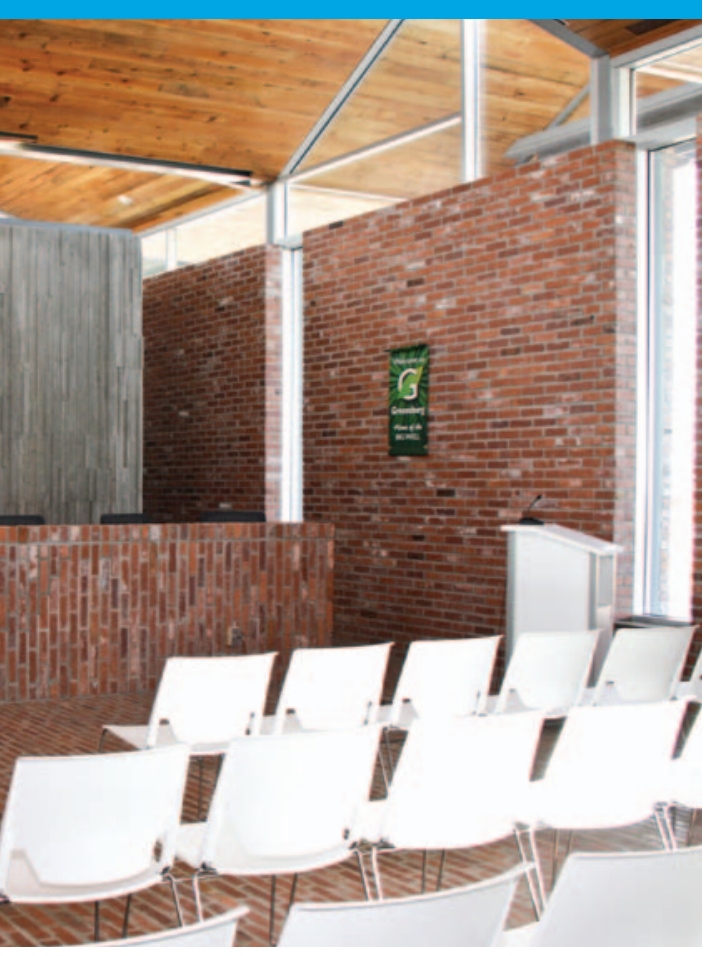

\section{Design Team}

Owners:

City of Greensburg

Builder and Construction Manager:

Orr Construction Management

\section{Architect:}

Berkible Nelson Immenschuh

McDowell Architects

\section{Civil Engineer:}

Professional Engineering Consultants

\section{Structural Engineer:}

Bob D. Campbell

\section{Mechanical, Electrical, and \\ Plumbing Engineer:}

BGR Engineers

\section{Energy Modeling:}

BGR Engineers

\section{Commissioning:}

Dome-Tech, Inc.

\section{Results}

According to energy analysis modeling results, City Hall is 38\% more energy efficient than an ASHRAE-compliant building of the same size and shape. Applying the savings from the 4.8-kW PV system, City Hall achieves an additional $8 \%$ in annual electricity savings for a total energy use savings of approximately $46 \%$.

\section{Annual Energy Cost Savings}

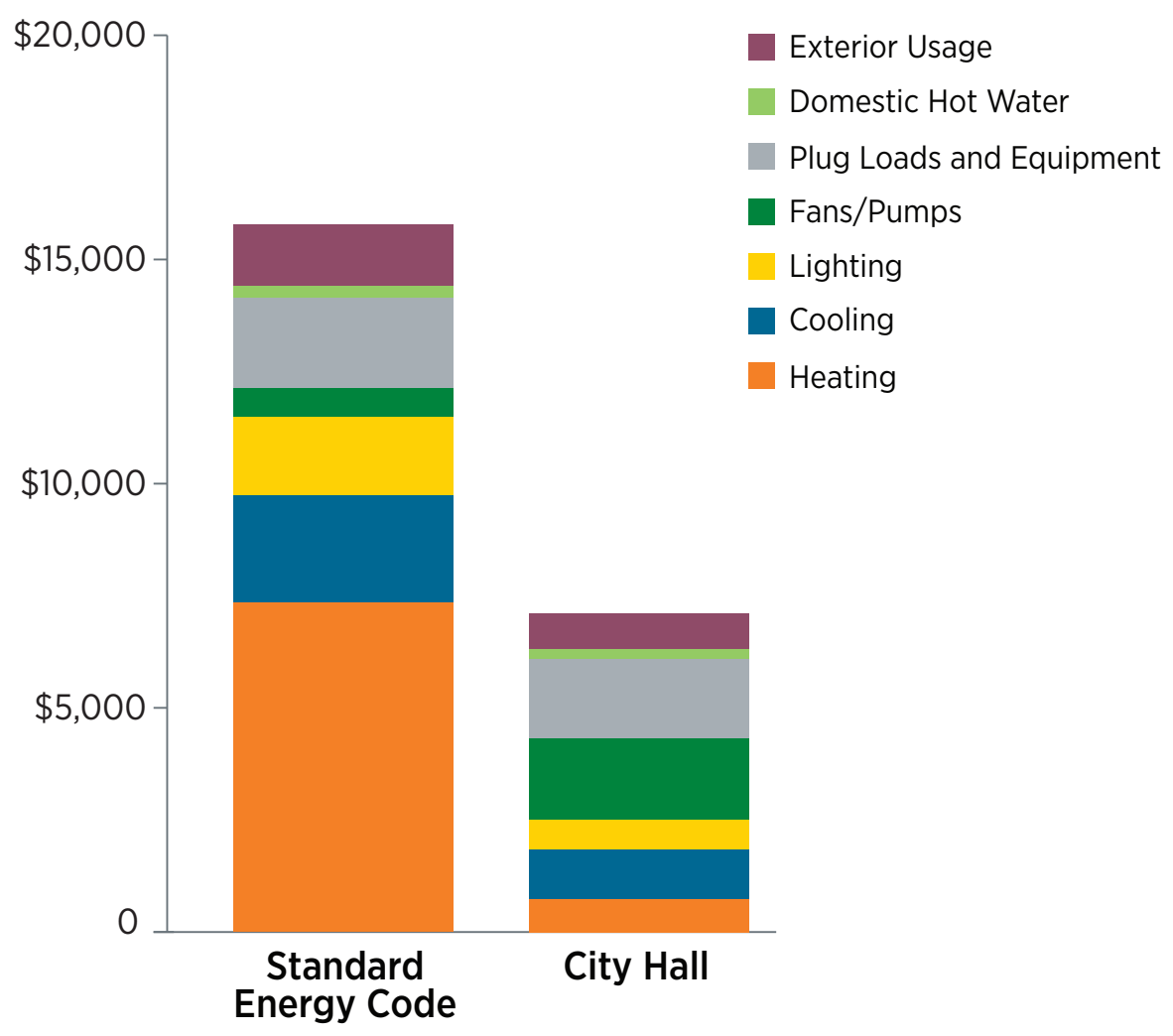

Energy modeling indicates that annual energy costs for a building similar to Greensburg City Hall built to standard code (the left column) would be approximately $\$ 15,800$. The right column represents the expected annual energy costs for Greensburg City Hall. Thanks to the PV and ground source heat pump systems, high-performance building envelope, and the Greensburg Wind Farm, City Hall's total annual energy costs are expected to be approximately $\$ 7,100-$ a reduction of more than $44 \%$.

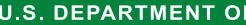 ENERGY}

Energy Efficiency \& Renewable Energy
This document is one in a series of documents outlining the options for and benefits of rebuilding green after a disaster. The series draws on lessons learned by teams from the U.S. Departs U.S. Department of Energy and its National Renewable Energy Laboratory as they helped the townspeople of Greensburg, Kansas, rebuild green after a devastating tornado. To see the other documents in this series, visit www.buildings.energy.gov/greensburg/.

\section{BNREL}

DOE/GO-102010-3152 September 2010

Printed with a renewable-source ink on paper containing at least $50 \%$ wastepaper, including $10 \%$ post consumer waste. 